\title{
Proposal of the genus Thermoactinomyces sensu stricto and three new genera, Laceyella, Thermoflavimicrobium and Seinonella, on the basis of phenotypic, phylogenetic and chemotaxonomic analyses
}

Correspondence Jung-Hoon Yoon jhyoon@kribb.re.kr

\author{
Jung-Hoon Yoon, In-Gi Kim, Yong-Kook Shint and Yong-Ha Park \\ Korea Research Institute of Bioscience and Biotechnology (KRIBB), PO Box 115, Yusong, \\ Taejon, Korea
}

\begin{abstract}
Phylogenetic analysis based on 16S rRNA gene sequences revealed that Thermoactinomyces species with validly published names can be assigned to four clusters or lineages. The type strains of Thermoactinomyces sacchari and Thermoactinomyces putidus were differentiated from the type strains of Thermoactinomyces vulgaris and Thermoactinomyces intermedius by the predominant menaquinone and fatty acid profiles. The type strains of Thermoactinomyces dichotomicus and Thermoactinomyces peptonophilus formed lines of descent distinct from other Thermoactinomyces species. Thermoactinomyces dichotomicus KCTC $3667^{\top}$ was distinguishable from the type strains of Thermoactinomyces vulgaris and Thermoactinomyces intermedius by the contents of two fatty acids, iso- $\mathrm{C}_{16: 0}$ and iso- $\mathrm{C}_{17: 0}$. Thermoactinomyces dichotomicus could be distinguished from other Thermoactinomyces species by DNA $\mathrm{G}+\mathrm{C}$ content and some phenotypic properties, particularly its property of forming a yellow colour. The type strain of Thermoactinomyces peptonophilus was distinguishable from other Thermoactinomyces species by differences in menaquinone profile, major fatty acids, DNA $\mathrm{G}+\mathrm{C}$ content and some physiological properties including optimal growth temperature. On the basis of these data, the creation of three new genera, Laceyella, Thermoflavimicrobium and Seinonella, is proposed in addition to the genus Thermoactinomyces sensu stricto. The genus Laceyella gen. nov. is proposed to accommodate Thermoactinomyces sacchari and Thermoactinomyces putidus as Laceyella sacchari comb. nov. and Laceyella putida comb. nov., the genus Thermoflavimicrobium gen. nov. is proposed for Thermoactinomyces dichotomicus as Thermoflavimicrobium dichotomicum comb. nov. and the genus Seinonella gen. nov. is proposed for Thermoactinomyces peptonophilus as Seinonella peptonophila comb. nov.
\end{abstract}

The genus Thermoactinomyces was proposed by Tsilinsky (1899) with the single species Thermoactinomyces vulgaris. Additional Thermoactinomyces species have since been described: Thermoactinomyces sacchari (Lacey, 1971), Thermoactinomyces peptonophilus (Nonomura \& Ohara, 1971), Thermoactinomyces candidus (Kurup et al., 1975), Thermoactinomyces intermedius (Kurup et al., 1980), Thermoactinomyces thalpophilus (Unsworth \& Cross, 1980) and Thermoactinomyces putidus (Lacey \& Cross, 1989).

Published online ahead of print on 10 September 2004 as DOI 10.1099/ijs.0.63203-0.

†Present address: Division of Genome Resources, National Genome Research Institute, National Institute of Health, 5 Nokbeon-dong, Seoul, Korea.

Abbreviations: DAP, diaminopimelic acid; FAME, fatty acid methyl ester.
Thermoactinomyces dichotomicus was proposed for 'Actinobifida dichotomica', described previously by Krasil'nikov \& Agre (1964) (Cross \& Goodfellow, 1973). More recently, Thermoactinomyces candidus was reclassified as a synonym of Thermoactinomyces vulgaris and Thermoactinomyces thalpophilus as a synonym of Thermoactinomyces sacchari (Yoon et al., 2000). Thermoactinomyces species were long recognized as actinomycetes because of their morphological characteristics, forming aerial and substrate mycelia. On the basis of endospore formation, DNA G $+C$ content and phylogenetic data, the genus Thermoactinomyces has now been placed within the family Bacillaceae, not the order Actinomycetales (Cross et al., 1971; Lacey \& Vince, 1971; Stackebrandt \& Woese, 1981; Lacey \& Cross, 1989; Park et al., 1993; Yoon \& Park, 2000).

Thermoactinomyces species are aerobic, Gram-positive and 
thermophilic, with the exception of one mesophilic species, Thermoactinomyces peptonophilis (Nonomura \& Ohara, 1971). The genus Thermoactinomyces contains mesodiaminopimelic acid (meso-DAP) but no diagnostic sugars in the cell wall (Lacey \& Cross, 1989), indicating that the wall chemotype is type III (Lechevalier \& Lechevalier, 1970). On the basis of differences in some phenotypic properties and predominant menaquinone profiles, together with the result of phylogenetic analysis, it was suggested that the genus Thermoactinomyces might be a heterogeneous group containing more than one genus (Yoon \& Park, 2000). In particular, Thermoactinomyces species were found to have different predominant menaquinone profiles (Collins et al., 1982; Tseng et al., 1990). Accordingly, the aim of the present study was to elucidate the exact taxonomic status of the genus Thermoactinomyces by a comparative chemotaxonomic analysis using newly determined menaquinone and fatty acid profiles together with phenotypic comparisons and phylogenetic analysis based on 16S rRNA gene sequences.

Thermoactinomyces vulgaris KCTC $9076^{\mathrm{T}}$, Thermoactinomyces vulgaris KCTC 9557 (previously the type strain of Thermoactinomyces candidus), Thermoactinomyces intermedius KCTC $9646^{\mathrm{T}}$, Thermoactinomyces sacchari KCTC $9790^{\mathrm{T}}$, Thermoactinomyces sacchari KCTC 9789 (previously the type strain of Thermoactinomyces thalpophilus), Thermoactinomyces putidus KCTC $3666^{\mathrm{T}}$, Thermoactinomyces dichotomicus KCTC $3667^{\mathrm{T}}$ and Thermoactinomyces peptonophilus KCTC $9740^{\mathrm{T}}$ were used in this study. Cell biomass for analyses of isoprenoid quinones and fatty acid methyl esters (FAMEs) was obtained from cultivation in liquid SY medium which contained $\left(\mathrm{l}^{-1}\right.$ tap water $) 15 \mathrm{~g}$ starch, $10 \mathrm{~g}$ yeast extract and $0.5 \mathrm{~g} \mathrm{MgSO}_{4}$. Since the SY medium showed good growth for all Thermoactinomyces species, it was used in this study for experimental standardization. All strains, except Thermoactinomyces peptonophilus, were cultivated at appropriate temperatures between 45 and $55^{\circ} \mathrm{C}$; Thermoactinomyces peptonophilus was cultivated at $35^{\circ} \mathrm{C}$. Hydrolysis of hypoxanthine, tyrosine and xanthine for Thermoactinomyces peptonophilus KCTC $9740^{\mathrm{T}}$ was tested on solid SY medium using the substrate concentrations described by Cowan \& Steel (1965). Isoprenoid quinones were analysed as described by Komagata \& Suzuki (1987) using reversed-phase HPLC. For quantitative analysis of cellular fatty acid composition, freeze-dried cells (approx. $7 \mathrm{mg}$ ) were used and FAMEs were extracted and prepared according to the standard protocol of the MIDI/ Hewlett Packard Microbial Identification System (Sasser, 1990). Chromosomal DNA was isolated and purified according to the method described previously (Yoon et al., 1996), with the exception that RNase T1 was used together with RNase A. The DNA G + C content was determined by the method of Tamaoka \& Komagata (1984) with the modification that DNA was hydrolysed and the resultant nucleotides were analysed by reversed-phase HPLC. Phylogenetic analyses based on 16S rRNA gene sequences were performed with the sequences of Thermoactinomyces species determined by Yoon \& Park (2000). Alignment of $16 \mathrm{~S}$ rRNA gene sequences was carried out using CLUSTAL $\mathrm{W}$ software (Thompson et al., 1994). Evolutionary distance matrices were calculated using the algorithm of Jukes \& Cantor (1969) with the program DNADIST within the PHYLIP package (Felsenstein, 1993). The phylogenetic tree was constructed by using the neighbour-joining method (Saitou \& Nei, 1987) with the program NEIGHBOR of the same package. The stability of relationships was assessed by a bootstrap analysis of 1000 datasets by using the programs SEQBOOT, DNADIST, NEIGHBOR and CONSENSE of the PHYLIP package.

In the neighbour-joining phylogenetic tree based on $16 \mathrm{~S}$ rRNA gene sequences, Thermoactinomyces species have been found to form differential clusters or independent lineages (Fig. 1; Yoon \& Park, 2000). Thermoactinomyces vulgaris KCTC $9076^{\mathrm{T}}$, Thermoactinomyces vulgaris KCTC 9557 and Thermoactinomyces intermedius KCTC $9646^{\mathrm{T}}$ formed one coherent cluster and Thermoactinomyces sacchari KCTC $9790^{\mathrm{T}}$, Thermoactinomyces sacchari KCTC 9789 and Thermoactinomyces putidus KCTC $3666^{\mathrm{T}}$ formed a second coherent cluster (Fig. 1; Yoon \& Park, 2000). Thermoactinomyces dichotomicus KCTC $3667^{\mathrm{T}}$ and Thermoactinomyces peptonophilus KCTC $9740^{\mathrm{T}}$ formed separate phylogenetic lineages independent of the clusters comprising other Thermoactinomyces species (Fig. 1). The same tree topology was also found in trees generated with the maximum-likelihood and maximum-parsimony algorithms (Fig. 1). Thermoactinomyces dichotomicus KCTC $3667^{\mathrm{T}}$ and Thermoactinomyces peptonophilus KCTC $9740^{\mathrm{T}}$ exhibited relatively low 16S rRNA gene similarity levels, of 90.1$94 \cdot 2 \%$ and $90 \cdot 1-91 \cdot 6 \%$, respectively, to the type strains of the other Thermoactinomyces species.

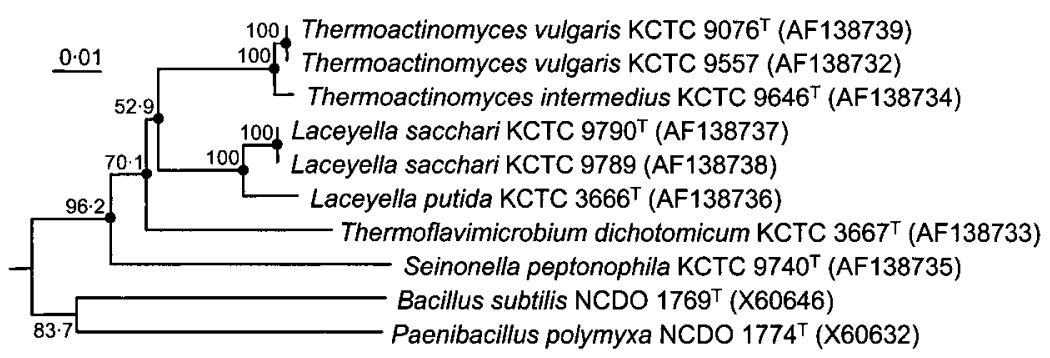

Fig. 1. Neighbour-joining tree based on 16S rRNA gene sequences showing the phylogenetic relationships of Thermoactinomyces species. Scale bar, 0.01 substitutions per nucleotide position. Bootstrap values (expressed as percentages of 1000 replications) greater than $50 \%$ are shown at branch points. Escherichia coli was used as the outgroup. Dots indicate nodes that were also recovered in maximum-likelihood and maximum-parsimony trees. 
This phylogenetic differentiation correlated with differences in predominant menaquinones and cellular fatty acids and physiological properties. In the study of Tseng et al. (1990), the type strains of Thermoactinomyces vulgaris (89\% MK-7), Thermoactinomyces candidus (89\% MK-7) and Thermoactinomyces intermedius (90\% MK-7) were reported to have MK-7 as the predominant menaquinone, whereas the type strains of Thermoactinomyces sacchari (75\% MK-9) and Thermoactinomyces thalpophilus (75\% MK-9) had MK-9 as the predominant menaquinone. The type strain of Thermoactinomyces putidus and Thermoactinomyces putidus JCM 3213 were found to have MK-9 as the predominant menaquinone (Collins et al., 1982; Tseng et al., 1990). The same results have been obtained from our study. Thermoactinomyces vulgaris KCTC $9076^{\mathrm{T}}$, Thermoactinomyces vulgaris KCTC 9557 (previously the type strain of Thermoactinomyces candidus) and Thermoactinomyces intermedius KCTC $9646^{\mathrm{T}}$ contained MK-7 as the predominant menaquinone, at peak area ratios of approximately $74-83 \%$. Thermoactinomyces sacchari KCTC $9790^{\mathrm{T}}$, Thermoactinomyces sacchari KCTC 9789 (previously the type strain of Thermoactinomyces thalpophilus) and Thermoactinomyces putidus KCTC $3666^{\mathrm{T}}$ contained MK-9 as the predominant menaquinone, at peak area ratios of approximately 60-75\%. Thermoactinomyces sacchari KCTC $9790^{\mathrm{T}}$, Thermoactinomyces sacchari KCTC 9789 and Thermoactinomyces putidus KCTC $3666^{\mathrm{T}}$ could also be distinguished from Thermoactinomyces vulgaris KCTC $9076^{\mathrm{T}}$, Thermoactinomyces vulgaris KCTC 9557 and Thermoactinomyces intermedius KCTC $9646^{\mathrm{T}}$ by differences in the contents of some fatty acids, particularly anteiso- $\mathrm{C}_{15: 0}$ and iso- $\mathrm{C}_{17: 0}$ (Table 1). Accordingly, Thermoactinomyces sacchari and Thermoactinomyces putidus can be differentiated from Thermoactinomyces vulgaris and Thermoactinomyces intermedius on the basis of menaquinone and fatty acid profiles as well as phylogenetic distinctiveness, although their morphological properties are similar (Tables 1 and 2).

Thermoactinomyces dichotomicus KCTC $3667^{\mathrm{T}}$ was found to have MK-7 (85\%) as the predominant menaquinone. This result is consistent with those of Collins et al. (1982) and Tseng et al. (1990). Although Thermoactinomyces dichotomicus KCTC $3667^{\mathrm{T}}$ showed a fatty acid profile similar to those of Thermoactinomyces vulgaris KCTC $9076^{\mathrm{T}}$, Thermoactinomyces vulgaris KCTC 9557 and Thermoactinomyces intermedius KCTC $9646^{\mathrm{T}}$, it showed some differences from these three strains in the contents of two fatty acids, iso$\mathrm{C}_{16: 0}$ and iso- $\mathrm{C}_{17: 0}$ (Table 1). Thermoactinomyces dichotomicus can be distinguished from other Thermoactinomyces species by differences in some phenotypic properties, including its morphological property of forming a yellow colour (Lacey \& Cross, 1989) (Table 2).

Thermoactinomyces peptonophilus KCTC $9740^{\mathrm{T}}$ formed a phylogenetic lineage distinct from other Thermoactinomyces species and exhibited low 16S rRNA gene sequence similarity $(90 \cdot 1-91.6 \%)$ to the type strains of other Thermoactinomyces species with validly published names.
Table 1. Percentage cellular fatty acid compositions of Thermoactinomyces species on SY medium

Strains: 1, T. vulgaris KCTC $9076^{\mathrm{T}}$; 2, T. vulgaris KCTC 9557; 3 , T. intermedius KCTC $9646^{\mathrm{T}} ; 4$, T. sacchari KCTC $9790^{\mathrm{T}} ; 5$, T. sacchari KCTC 9789; 6, T. putidus KCTC $3666^{\mathrm{T}} ;$ 7, T. dichotomicus KCTC $3667^{\mathrm{T}} ; 8$, T. peptonophilus KCTC $9740^{\mathrm{T}}$. Fatty acids representing $1 \%$ of the total fatty acids of at least one of the strains are shown. -, Not detected.

\begin{tabular}{|lrrrrrrrr|}
\hline Fatty acid & $\mathbf{1}$ & $\mathbf{2}$ & $\mathbf{3}$ & $\mathbf{4}$ & $\mathbf{5}$ & $\mathbf{6}$ & $\mathbf{7}$ & $\mathbf{8}$ \\
\hline Straight-chain & & & & & & & & \\
$\mathrm{C}_{14: 0}$ & $0 \cdot 5$ & $0 \cdot 8$ & $1 \cdot 2$ & $2 \cdot 8$ & $6 \cdot 2$ & $2 \cdot 6$ & $5 \cdot 8$ & $1 \cdot 9$ \\
$\mathrm{C}_{15: 0}$ & $0 \cdot 2$ & $0 \cdot 3$ & $0 \cdot 2$ & $0 \cdot 5$ & $0 \cdot 7$ & $0 \cdot 7$ & $1 \cdot 8$ & $0 \cdot 4$ \\
$\mathrm{C}_{16: 0}$ & $2 \cdot 1$ & $2 \cdot 8$ & $3 \cdot 5$ & $3 \cdot 8$ & $8 \cdot 1$ & $7 \cdot 2$ & $6 \cdot 7$ & $9 \cdot 2$ \\
Unsaturated & & & & & & & & \\
$\mathrm{C}_{16: 1} \omega 7 c$ alcohol & - & - & - & - & - & - & - & $2 \cdot 0$ \\
$\mathrm{C}_{16: 1} \omega 11 c$ & - & - & - & - & - & - & - & $7 \cdot 0$ \\
$\mathrm{C}_{18: 1} \omega 9 c$ & - & $0 \cdot 4$ & $0 \cdot 7$ & $0 \cdot 4$ & $0 \cdot 3$ & - & - & $1 \cdot 1$ \\
Branched-chain $_{11}$ & & & & & & & & \\
iso- $\mathrm{C}_{11: 0}$ & $1 \cdot 0$ & $0 \cdot 4$ & $0 \cdot 4$ & - & - & - & - & - \\
iso- $\mathrm{C}_{13: 0}$ & $1 \cdot 9$ & $1 \cdot 7$ & $1 \cdot 8$ & $0 \cdot 5$ & $0 \cdot 5$ & $0 \cdot 3$ & $1 \cdot 2$ & $0 \cdot 1$ \\
iso- $\mathrm{C}_{14: 0}$ & $0 \cdot 9$ & $1 \cdot 0$ & $0 \cdot 8$ & $2 \cdot 3$ & $3 \cdot 2$ & $2 \cdot 4$ & $5 \cdot 8$ & $26 \cdot 9$ \\
iso- $\mathrm{C}_{15: 0}$ & $54 \cdot 3$ & $51 \cdot 8$ & $55 \cdot 1$ & $47 \cdot 5$ & $42 \cdot 3$ & $31 \cdot 7$ & $46 \cdot 7$ & $3 \cdot 1$ \\
anteiso- $\mathrm{C}_{15: 0}$ & $10 \cdot 2$ & $13 \cdot 4$ & $11 \cdot 4$ & $28 \cdot 0$ & $24 \cdot 8$ & $28 \cdot 4$ & $12 \cdot 7$ & $26 \cdot 5$ \\
iso-C $\mathrm{C}_{16: 0}$ & $4 \cdot 2$ & $4 \cdot 3$ & $3 \cdot 0$ & $5 \cdot 2$ & $6 \cdot 4$ & $7 \cdot 6$ & $10 \cdot 3$ & $15 \cdot 7$ \\
iso- $\mathrm{C}_{17: 0}$ & $18 \cdot 6$ & $15 \cdot 5$ & $16 \cdot 3$ & $5 \cdot 0$ & $4 \cdot 2$ & $9 \cdot 2$ & $7 \cdot 0$ & $1 \cdot 7$ \\
anteiso- $\mathrm{C}_{17: 0}$ & $5 \cdot 4$ & $6 \cdot 2$ & $3 \cdot 9$ & $3 \cdot 5$ & $2 \cdot 8$ & $8 \cdot 3$ & $1 \cdot 3$ & $1 \cdot 6$ \\
& & & & & & & & \\
\hline
\end{tabular}

Thermoactinomyces peptonophilus differed from other Thermoactinomyces species in some physiological properties, including lack of resistance to novobiocin, requirement for a high peptone concentration for growth, optimal temperature of $35^{\circ} \mathrm{C}$ and others (Nonomura \& Ohara, 1971; Lacey \& Cross, 1989). Thermoactinomyces peptonophilus KCTC $9740^{\mathrm{T}}$ contained MK-7 (59\%) as the predominant menaquinone, and significant amounts of MK-9 (17\%), MK-10 (14\%) and MK-8 (10\%) were also present. The cellular fatty acid profile of Thermoactinomyces peptonophilus KCTC $9740^{\mathrm{T}}$ showed clear difference from those of the type strains of other Thermoactinomyces species (Table 1). While fatty acid iso- $\mathrm{C}_{14: 0}$ and unsaturated fatty acids were major components in Thermoactinomyces peptonophilus KCTC $9740^{\mathrm{T}}$, they were minor components in the type strains of other Thermoactinomyces species (Table 1). The fatty acid iso- $\mathrm{C}_{15: 0}$ was a major component in the type strains of other Thermoactinomyces species, whereas it was a minor component in Thermoactinomyces peptonophilus KCTC $9740^{\mathrm{T}}$ (Table 1). The DNA G+C contents of Thermoactinomyces dichotomicus KCTC $3667^{\mathrm{T}}$ and Thermoactinomyces peptonophilus KCTC $9740^{\mathrm{T}}$ were lower than those of the type strains of other Thermoactinomyces species: Thermoactinomyces dichotomicus KCTC $3667^{\mathrm{T}}$ and Thermoactinomyces peptonophilus KCTC $9740^{\mathrm{T}}$ had respective DNA G $+\mathrm{C}$ contents of 43 and $40 \mathrm{~mol} \%$, whereas the type strains of other Thermoactinomyces species had DNA G + C contents of 48-49 $\mathrm{mol} \%$. 
Table 2. Differential phenotypic characteristics of the emended genus Thermoactinomyces and newly proposed genera

Data from Nonomura \& Ohara (1971), Lacey \& Cross (1989) and this study. +, Positive; -, negative; ND, not detected.

\begin{tabular}{|c|c|c|c|c|}
\hline Characteristic & Thermoactinomyces & Laceyella & Thermoflavimicrobium & Seinonella \\
\hline Colour of aerial mycelium & White & White & Yellow & White \\
\hline Sessile spores on dichotomously branched sporophores & - & - & + & - \\
\hline Growth on $25 \mu \mathrm{g}$ novobiocin $\mathrm{ml}^{-1}$ & + & + & + & - \\
\hline \multicolumn{5}{|l|}{ Degradation of: } \\
\hline Casein & + & + & + & - \\
\hline Gelatin & + & + & + & - \\
\hline Starch & - & + & - & - \\
\hline Hypoxanthine & - & - & + & - \\
\hline Xanthine & - & - & + & - \\
\hline Optimal temperature for growth $\left({ }^{\circ} \mathrm{C}\right)$ & $50-55$ & $48-55$ & 55 & 35 \\
\hline Predominant menaquinone & MK-7 & MK-9 & MK-7 & MK-7 \\
\hline Major menaquinone $(\mathrm{s})^{\star}$ & MK-8 or MK-9 & $\begin{array}{l}\text { MK-7 or MK-8 } \\
\quad \text { or MK-10 }\end{array}$ & $\mathrm{ND}$ & $\begin{array}{c}\text { MK-8, MK-9, } \\
\text { MK-10 }\end{array}$ \\
\hline Major fatty acids & $\begin{array}{l}\text { iso- } \mathrm{C}_{15: 0} \text {; iso- } \mathrm{C}_{17: 0} \\
\quad \text { anteiso- } \mathrm{C}_{15: 0}\end{array}$ & $\begin{array}{l}\text { iso- } \mathrm{C}_{15: 0} \\
\text { anteiso- } \mathrm{C}_{15: 0}\end{array}$ & $\begin{array}{l}\text { iso- } \mathrm{C}_{15: 0} \\
\text { anteiso- } \mathrm{C}_{15: 0} \\
\text { iso- } \mathrm{C}_{16: 0}\end{array}$ & $\begin{array}{l}\text { iso- } \mathrm{C}_{14: 0} \\
\text { anteiso- } \mathrm{C}_{15: 0} \\
\text { iso- } \mathrm{C}_{16: 0}\end{array}$ \\
\hline DNA G $+\mathrm{C}$ content $(\mathrm{mol} \%)$ & 48 & $48-49$ & 43 & 40 \\
\hline
\end{tabular}

${ }^{\star}$ Other components making up $>10 \%$ peak area ratio are shown.

On the basis of the phylogenetic and phenotypic characteristics presented, it appears to be more appropriate that Thermoactinomyces species are divided into four different genera, including the genus Thermoactinomyces sensu stricto. In conclusion, we propose that Thermoactinomyces sacchari and Thermoactinomyces putidus are reclassified in a new genus Laceyella gen. nov. as Laceyella sacchari comb. nov. and Laceyella putida comb. nov., respectively, Thermoactinomyces dichotomicus be reclassified in a new genus Thermoflavimicrobium gen. nov. as Thermoflavimicrobium dichotomicum comb. nov. and Thermoactinomyces peptonophilus be reclassified in a new genus Seinonella gen. nov. as Seinonella peptonophila comb. nov.

\section{Emended description of the genus Thermoactinomyces Tsilinsky 1899}

Cells are aerobic, Gram-positive, non-acid-fast and chemoorganotrophic. Aerial mycelium is abundant and white. Well-developed, branched and septate substrate mycelium is formed. Endospores are sessile and formed singly on aerial and substrate hyphae or on unbranched short sporophores. Thermophilic. Growth occurs at $55^{\circ} \mathrm{C}$ but not at $30^{\circ} \mathrm{C}$. Further descriptive information is given by Lacey \& Cross (1989). Additional characters found in this study are as follows. Predominant menaquinone is MK-7. Major fatty acid is iso- $\mathrm{C}_{15: 0}$, and significant amounts of iso- $\mathrm{C}_{17: 0}$ are present. Two species are assigned to the emended genus Thermoactinomyces: Thermoactinomyces vulgaris and Thermoactinomyces intermedius. The DNA $\mathrm{G}+\mathrm{C}$ content of the type strains of Thermoactinomyces vulgaris and Thermoactinomyces intermedius is $48 \mathrm{~mol} \%$ (determined by HPLC in this study). The type species is Thermoactinomyces vulgaris Tsilinsky 1899.

\section{Description of Laceyella gen. nov.}

Laceyella (La.cey.el'la. N.L. dim. fem. n. Laceyella named to honour Dr John Lacey, an English microbiologist, for his contribution to the taxonomy of the genus Thermoactinomyces and actinomycetes).

Cells are aerobic, Gram-positive, non-acid-fast and chemoorganotrophic. Aerial and substrate mycelia are formed. Aerial mycelium is white. Yellow-brown or greyish-yellow soluble pigment may be produced. Sessile endospores may be produced on sporophores. Thermophilic. The cell-wall peptidoglycan contains meso-DAP but no characteristic sugars. Additional characters found in this study are as follows. Predominant menaquinone is MK-9. Major fatty acids are iso- $\mathrm{C}_{15: 0}$ and anteiso- $\mathrm{C}_{15: 0}$. DNA G+C content of the type strains of two species is $48-49$ mol\% (determined by HPLC in this study). The type species is Laceyella sacchari (Lacey 1971).

\section{Description of Laceyella sacchari (Lacey 1971) comb. nov.}

Basonym: Thermoactinomyces sacchari Lacey 1971.

The description is the same as that given by Lacey \& Cross (1989). Some additional characteristics are as follows. A sparse, transient, tufted aerial mycelium, rapidly autolysing and depositing endospores in a thick layer, is produced on the surface of yeast malt or nutrient agar supplemented with 
$1 \%(w / v)$ glucose. Growth on nutrient agar is poor, restricted and thin with no aerial mycelium and few spores. Endospores are produced on sporophores up to $3 \mu \mathrm{m}$ long. Yellow-brown soluble pigment may be produced. Growth occurs at $55^{\circ} \mathrm{C}$. Growth at $30^{\circ} \mathrm{C}$ is variable. Water-soluble melanin is produced or not on CYC agar with $0.5 \%(\mathrm{w} / \mathrm{v})$ L-tyrosine. Elastin, DNA, RNA and Tweens 20, 40, 60 and 80 are degraded. Adenine, cellulose, guanine and keratin are not degraded. Degradation of aesculin, arbutin, chitin and tyrosine is variable. D-Glucose, D-fructose and Dmannitol are utilized as carbon sources. Cellulose, mesoinositol, D-raffinose, L-rhamnose and D-xylose are not utilized. Utilization of L-arabinose, D-mannose and sucrose is variable. No growth occurs in the presence of $5 \%(\mathrm{w} / \mathrm{v})$ $\mathrm{NaCl}$; growth in the presence of $1 \%(\mathrm{w} / \mathrm{v}) \mathrm{NaCl}$ is variable. Further descriptive information is given by Lacey \& Cross (1989) or is shown in Table 1. The DNA G+C content of the type strain is $48 \mathrm{~mol} \%$ (determined by HPLC in this study). Isolated from sugar cane, self-heated sugar cane bagasse, filter press muds, sugar mills and soil.

The type strain is ATCC $27375^{\mathrm{T}}\left(=\mathrm{KCTC} 9790^{\mathrm{T}}=\mathrm{DSM}\right.$ $43356^{\mathrm{T}}=$ NCIMB $10486^{\mathrm{T}}$ ).

\section{Description of Laceyella putida (Lacey and Cross 1989) comb. nov.}

Basonym: Thermoactinomyces putidus Lacey and Cross 1989.

The description is the same as that given by Lacey \& Cross (1989). Some additional characteristics are as follows. Colonies are often very wrinkled and puckered with endospores formed on short and unbranched sporophores. Aerial mycelium white, but may appear cream, pale yellow or yellowish-brown due to yellowish-brown substrate mycelium. Sporing hyphae lyse quickly, leaving spores on the surface of agar. Greyish-yellow soluble pigment may be produced. Brown, water-soluble melanin pigment is produced on CYC agar supplemented with $0.5 \%(\mathrm{w} / \mathrm{v}) \mathrm{L}-$ tyrosine. Sensitive to $1 \%(\mathrm{w} / \mathrm{v}) \mathrm{NaCl}$. Growth at 55 and $30{ }^{\circ} \mathrm{C}$ is variable. Degradation of aesculin, arbutin and chitin is variable. Tyrosine is degraded, but DNA is not. D-Glucose and sucrose are utilized as carbon sources. D-Fructose, glycerol, D-mannitol, D-mannose, D-ribose and D-trehalose are not utilized. Further descriptive information is given by Lacey \& Cross (1989) or is shown in Table 1. The DNA $\mathrm{G}+\mathrm{C}$ content of the type strain is $49 \mathrm{~mol} \%$ (determined by HPLC in this study). Isolated from soil, deep mud cores and a lung biopsy of a patient with farmer's lung.

The type strain is NCIMB $12324^{\mathrm{T}}\left(=\right.$ ATCC $49853^{\mathrm{T}}=\mathrm{KCTC}$ $3666^{\mathrm{T}}=$ DSM $44608^{\mathrm{T}}$ ).

\section{Description of Thermoflavimicrobium gen. nov.}

Thermoflavimicrobium (Ther'mo.fla.vi.mi.cro'bi.um. Gr. adj. thermos hot; L. adj. flavus yellow; Gr. adj. mikros small; Gr. n. bios life; N.L. neut. n. Thermoflavimicrobium a thermophilic yellow-coloured microbe).
Cells are aerobic, Gram-positive, non-acid-fast and chemoorganotrophic. Aerial and substrate mycelia are formed. Aerial mycelium is yellow and abundant. Sessile endospores are produced on dichotomously branched sporophores. Thermophilic. The cell-wall peptidoglycan contains mesoDAP but no characteristic sugars. Additional characters found in this study are as follows. Predominant menaquinone is MK-7. Major fatty acids are iso- $C_{15: 0}$, anteiso- $C_{15: 0}$ and iso- $\mathrm{C}_{16: 0}$. The DNA G $+\mathrm{C}$ content of the type strain of the type species is $43 \mathrm{~mol} \%$ (determined by HPLC in this study). The type species is Thermoflavimicrobium dichotomicum (Cross and Goodfellow 1973).

\section{Description of Thermoflavimicrobium dichotomicum (Cross and Goodfellow 1973) comb. nov.}

Basonym: Thermoactinomyces dichotomicus (ex Krasil'nikov and Agre 1964) Cross and Goodfellow 1973.

The description is the same as that given by Lacey \& Cross (1989). Some additional characteristics are as follows. Colonies are yellow to orange, distinctively fast-growing with dichotomously branched mycelium and sporophores on nutrient agar and $\mathrm{CYC}$ agar at $55^{\circ} \mathrm{C}$. Growth occurs at $55^{\circ} \mathrm{C}$, but not at $30^{\circ} \mathrm{C}$. Margins of colonies are entire on CYC agar. Exosporium surrounding the spores is present. Elastin, DNA, guanine, RNA and Tweens 20, 40, 60 and 80 are degraded. Aesculin, adenine, arbutin, cellulose, hippurate, keratin and tyrosine are not degraded. Growth occurs in the presence of $0.5 \%(\mathrm{w} / \mathrm{v}) \mathrm{NaCl}$, but not in the presence of $1.0 \%(\mathrm{w} / \mathrm{v}) \mathrm{NaCl}$. L-Arabinose, D-galactose, D-glucose, glycerol, lactose, maltose, mannitol, mesoinositol, D-raffinose, L-rhamnose, D-sorbitol, starch, sucrose and D-xylose are utilized as carbon sources. Further descriptive information is given by Lacey \& Cross (1989) or is shown in Table 1 . The DNA G $+\mathrm{C}$ content of the type strain is $43 \mathrm{~mol} \%$ (determined by HPLC in this study). Isolated from soil and mushroom compost.

The type strain is KCTC $3667^{\mathrm{T}}\left(=\right.$ ATCC $49854^{\mathrm{T}}=\mathrm{JCM}$ $9688^{\mathrm{T}}=$ DSM $44778^{\mathrm{T}}$ ).

\section{Description of Seinonella gen. nov.}

Seinonella (Sei.no.nel'la. N.L. dim. fem. n. Seinonella named to honour Dr Akio Seino, a Japanese microbiologist, for his contribution to the taxonomy of the genus Thermoactinomyces and actinomycetes).

Aerial mycelium is white and substrate mycelium is white to yellowish brown. Endospores are sessile on flexuous branches of the aerial mycelium and on the substrate mycelium. Mesophilic. The cell-wall peptidoglycan contains meso-DAP. Additional characters found in this study are as follows. Predominant menaquinone is MK-7 and significant amounts of MK-8, MK- 9 and MK-10 are present. The major fatty acids are iso- $\mathrm{C}_{14: 0}$ and anteiso- $\mathrm{C}_{15: 0}$. The type species is Seinonella peptonophila (Nonomura and Ohara 1971). 


\section{Description of Seinonella peptonophila (Nonomura and Ohara 1971) comb. nov.}

Basonym: Thermoactinomyces peptonophilus Nonomura and Ohara 1971. Note: Rule 61 of the Bacteriological Code prevents the correction of the epithet to 'peptoniphila'.

The description is the same as that given by Nonomura \& Ohara (1971) and Lacey \& Cross (1989). High concentrations of peptone or yeast extract $(3 \% \mathrm{w} / \mathrm{v})$ in addition to $B$ vitamins are essential for good growth. A low concentration of glycerol or glucose $(0.2 \% \mathrm{w} / \mathrm{v})$ is favourable for aerial mycelium production. No distinct soluble pigments are produced. Optimal growth temperature is $35^{\circ} \mathrm{C}$; poor growth at $25^{\circ} \mathrm{C}$ and no growth at $45^{\circ} \mathrm{C}$. Optimal pH for growth is $7 \cdot 0-8 \cdot 0$; no growth at $\mathrm{pH} 5 \cdot 0$. Nitrate reduction is negative. Tyrosine is not hydrolysed. Further descriptive information is given by Nonomura \& Ohara (1971) and Lacey \& Cross (1989) or is shown in Table 1. The DNA $\mathrm{G}+\mathrm{C}$ content of the type strain is $40 \mathrm{~mol} \%$ (determined by HPLC in this study). Isolated from soil.

The type strain is KCTC $9740^{\mathrm{T}}\left(=\mathrm{ATCC} 27302^{\mathrm{T}}=\mathrm{JCM}\right.$ $10113^{\mathrm{T}}=$ DSM $44666^{\mathrm{T}}$ ).

\section{Acknowledgements}

This work was supported by the 21C Frontier Program of Microbial Genomics and Applications (grant MG02-0401-001-1-0-0) and partially by a grant from the KRIBB Research Initiative Program.

\section{References}

Collins, M. D., Mackillop, G. C. \& Cross, T. (1982). Menaquinone composition of members of the genus Thermoactinomyces. FEMS Microbiol Lett 13, 151-153.

Cross, T. \& Goodfellow, M. (1973). Taxonomy and classification of the actinomycetes. In Actinomycetales: Characteristics and Practical Importance, pp. 11-112. Edited by G. Sykes \& F. A. Skinner. London: Academic Press.

Cross, T., Davies, F. L. \& Walker, P. D. (1971). Thermoactinomyces vulgaris. I. Fine structure of the developing endospores. In Spore Research, pp. 175-187. Edited by A. N. Barker, G. W. Gould \& J. A. Wolf. London: Academic Press.

Felsenstein, J. (1993). PHYLIP: Phylogenetic Inference Package, version 3.5. Distributed by the author. Department of Genetics, University of Washington, Seattle, USA.

Jukes, T. H. \& Cantor, C. R. (1969). Evolution of protein molecules. In Mammalian Protein Metabolism, vol. 3, pp. 21-132. Edited by H. N. Munro. New York: Academic Press.

Komagata, K. \& Suzuki, K. (1987). Lipids and cell-wall analysis in bacterial systematics. Methods Microbiol 19, 161-203.

Krasil'nikov, N. A. \& Agre, N. S. (1964). A new actinomycete genus Actinobifida n. gen. yellow group - Actinobifida dichotomica n. sp. Mikrobiologiya 33, 935-943 (in Russian).

Kurup, V. P., Barboriak, J. J., Fink, J. N. \& Lechevalier, M. P. (1975). Thermoactinomyces candidus, a new species of thermophilic actinomycetes. Int J Syst Bacteriol 25, 150-154.
Kurup, V. P., Hollick, G. E. \& Pagan, E. F. (1980). Thermoactinomyces intermedius, a new species of amylase negative thermophilic actinomycetes. Science - Ciencia Bol Cien Sur 7, 104-108.

Lacey, J. (1971). Thermoactinomyces sacchari sp. nov., a thermophilic actinomycete causing bagassosis. J Gen Microbiol 66, 327-338.

Lacey, J. \& Cross, T. (1989). Genus Thermoactinomyces Tsiklinsky $1899,501^{\mathrm{AL}}$. In Bergey's Manual of Systematic Bacteriology, vol. 4, pp. 2574-2585. Edited by S. T. Williams, M. E. Sharpe \& J. G. Holt. Baltimore: Williams \& Wilkins.

Lacey, J. \& Vince, D. A. (1971). Endospore formation and germination in a new Thermoactinomyces species. In Spore Research, pp. 181-187. Edited by A. N. Barker, G. W. Gould \& J. A. Wolf. London: Academic Press.

Lechevalier, M. P. \& Lechevalier, H. A. (1970). A critical evaluation of the genera of aerobic actinomycetes. In The Actinomycetales, pp. 393-405. Edited by H. Prauser. Jena: Gustav Fischer.

Nonomura, H. \& Ohara, Y. (1971). Distribution of actinomycetes in soil. X. New genus and species of monosporic actinomycetes in soil. J Ferment Technol 49, 895-903.

Park, Y.-H., Kim, E., Yim, D.-G., Kho, Y.-H., Mheen, T.-I. \& Goodfellow, M. (1993). Supragenic classification of Thermoactinomyces vulgaris by nucleotide sequencing of $5 \mathrm{~S}$ ribosomal RNA. Zentbl Bakteriol 278, 469-478.

Saitou, N. \& Nei, M. (1987). The neighbor-joining method: a new method for reconstructing phylogenetic trees. Mol Biol Evol 4, 406-425.

Sasser, M. (1990). Identification of Bacteria by Gas Chromatography of Cellular Fatty Acids. Newark, DE: MIDI Inc.

Stackebrandt, E. \& Woese, C. R. (1981). Towards a phylogeny of the actinomycetes and related organisms. Curr Microbiol 5, 197-202.

Tamaoka, J. \& Komagata, K. (1984). Determination of DNA base composition by reverse-phase high-performance liquid chromatography. FEMS Microbiol Lett 25, 125-128.

Thompson, J. D., Higgins, D. G. \& Gibson, T. J. (1994). CLUSTAL W: improving the sensitivity of progressive multiple sequence alignment through sequence weighting, position-specific gap penalties and weight matrix choice. Nucleic Acids Res 22, 4673-4680.

Tseng, M., Kudo, T. \& Seino, A. (1990). Identification of thermophilic actinomycetes isolated from mushroom compost in Taiwan. Bull JFCC 6, 6-13.

Tsilinsky, P. (1899). On the thermophilic moulds. Ann Inst Pasteur 13, 500-505 (in French).

Unsworth, B. A. \& Cross, T. (1980). Thermophilic actinomycetes implicated in farmer's lung: numerical taxonomy of Thermoactinomyces species. In Microbiological Classification and Identification, pp. 389-390. Edited by M. Goodfellow \& R. G. Broad. London: Academic Press.

Yoon, J.-H. \& Park, Y.-H. (2000). Phylogenetic analysis of the genus Thermoactinomyces based on $16 \mathrm{~S}$ rDNA sequences. Int J Syst Evol Microbiol 50, 1081-1086.

Yoon, J.-H., Kim, H., Kim, S.-B., Kim, H.-J., Kim, W. Y., Lee, S. T., Goodfellow, M. \& Park, Y.-H. (1996). Identification of Saccharomonospora strains by the use of genomic DNA fragments and rRNA gene probes. Int J Syst Bacteriol 46, 502-505.

Yoon, J.-H., Shin, Y. K. \& Park, Y.-H. (2000). DNA-DNA relatedness among Thermoactinomyces species: Thermoactinomyces candidus as a synonym of Thermoactinomyces vulgaris and Thermoactinomyces thalpophilus as a synonym of Thermoactinomyces sacchari. Int J Syst Evol Microbiol 50, 1905-1908. 